\title{
Effects of Anthropogenic Activities and Eutrophication along River Chanchaga, Minna, Nigeria
}

\author{
Wakili, B. Y $Y^{1}$ (iD \\ Nsofor G.N ${ }^{2}$ \\ Suleiman, Y. M $\mathbf{M}^{3}$ \\ Mohammed. A. E ${ }^{4}$ \\ 1,o,s,t, Department of Geography, Federal University of Technology, Minna, Nigeria \\ Email:balawakilitreal@gmail.com
}

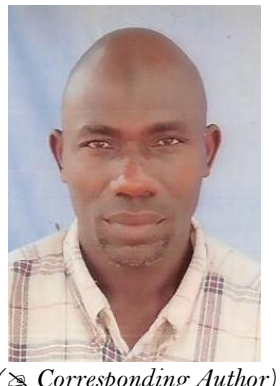

\begin{abstract}
River Chanchaga is the major source of drinking water in Minna, Nigeria. This river has been a medium to an increasing pollution loads from contaminated runoff from different land uses degrading aquatic ecosystem and water quality in the river.This paper investigates the threat of anthropogenic influence on river environment and aquatic ecosystem distortion of River Chanchaga, Minna, Nigeria. Field work which include interview and observation methods were used to collect data on effect of anthropogenic and eutrophication along the study area. A total of Two Hundred and Fifty (250) people accounting for $0.5 \%$ of the total population were interviewed, making it eight per each community in thirty settlements along the study area. Physical observation of deforestation around sample sites spatially distributed along River Chanchaga depicted in Figure 2 was carried out to study mining activities, farming practice, crop types, and fallow duration to generate the mean and percentages of different anthropogenic activities along the study area. The findings revealed that deforestation is links to high demand for fire wood, lumbering, irrigation farming bank-side mining for sand and gold as depicted in Plat 1 and 2. Eutrophication at the upper course of river is links to high inflow of agricultural wastes and seasonal nature of the river from site $\mathrm{A}$ to $\mathrm{C}$ evident from Table 4 and constant flow from site $\mathrm{C}$ to $\mathrm{K}$ as a result of released water from Tagwai Dam that keeps (site $\mathrm{C}$, the confluence of River Chanchaga and River Numui) middle and lower courses of River Chanchaga with sustainable moving water. The result further indicated that continue increase of pollution has a direct relationship to an increasing level of human activities like deforestation, mining activities and agricultural practices along the study area. The result also shows that there is decline in fallow duration as indicated in Table 1 and increase environmental related issues such as soil erosion, water floor (depth) reduction and distortion of river morphology of the study area. It is therefore recommended that the identified anthropogenic activities that lead to pollution and eutrophication such as river-side deforestation, irrigation farming, mining and other related environmental problems should be regulated and discourages to avoid further increase of pollution and distortion of river environment of the study area.
\end{abstract}

Keywords: Anthropogenic, Pollution, Deforestation, Eutrophication, Environment.

Citation | Wakili, B. Y; Nsofor G.N; Suleiman, Y. M; Mohammed. A. E (2017). Effects of Anthropogenic Activities and Eutrophication along River Chanchaga, Minna, Nigeria. Asian Review of Environmental and Earth Sciences, 4(1): 58-64

History

Received 18 November 2017

Published: 21 December 2017

Licensed: This work is licensed under a Creative Commons Attribution 3.0

License $(\mathrm{cc}) \boldsymbol{C}$

Publisher: Asian Online Journal Publishing Group

\section{Contents}

1. Introduction 


\section{Introduction}

There are many ways, by which several water sources include harbors, bays, creeks, canals, swamps, lakes, and streams, which come together and form a small network of river. In Nigeria, these water ways (rivers) have been the medium to an increasing pollution load from contaminated runoff water from agriculture, domestic (residential), industrial, commercial, institutional (schools, hospitals), recreational, like tourism centers and event centers Adakole and Annue [1]. Ogbogu and Hassan [2] made mention that contaminants usually carried into water bodies (stream/rivers) especially in areas of heavy anthropogenic activities degrade the aquatic habitat and water quality. To some level freshness is also attributed to geochemical and biochemical sedimentation [Q]. River Chanchaga is a major effluent receiving stream with many gutters inflow to it. It is also use for irrigation of crops as well as source of drinking water for cattle during the dry season period [3].

At the catchments, there is challenge of land cover destruction that affects negatively on the river (River Chanchaga) and reflected on the proliferation of water hyacinth infestation [4]. River Chanchaga presents a good example of localities that have undergone extensive land use and land cover changes since the attainment of independence and subsequent population growth. The development has been a threat to the sustainability of its natural resource endowments [5]. Public concern is now focused on how human impact on aquatic life or habitat loss and fragmentation are predominant factors affecting biodiversity loss [6]. Conservation strategies are therefore, needed in order to offset such impacts on animal populations.

Polluted water has direct effect on health in the form of bacterial or viral disease, production of cancer, genetic defects and varieties of acute and chronic toxicity in human beings [7]. Water pollution affects ecosystems through which an impact on human beings may not consequently be left. Hence, household detergents that contain phosphate may flow into Oligotrophic lakes and lead to eutrophication of the water bodies.

Muhammad [8] pointed to the socioeconomic importance of river and postulated that it is the modifier of micro climatic conditions around its immediate surroundings. Though the importance of the river is recognized the emanating situation along River Chanchaga is not environmentally friendly. This is true because the morphology of the river has been undergoing alteration and degradation of its environment.This challenge require and immediate attention to checked environmental degradations and eco-system disorders. This river is also for dry season irrigation farming and for domestic activities (such as construction of houses around its bank and neighboring village communities and excavation of sand [8].

\section{The Study Area}

River Chanchaga transverses Muya, Shiroro, Paikoro, Bosso and Katcha Local Government Areas and can be located on Longitude $6^{\circ} 33^{\prime} \mathrm{E}$ - Longitude $6^{\circ} 38^{\prime} \mathrm{E}$ and latitude $9^{\circ} 37^{\prime} \mathrm{N}$ - Latitude $9^{\circ} 40^{\prime} \mathrm{N}$. The total land area covered by the basin is $159,259 \mathrm{~km}[8]$.

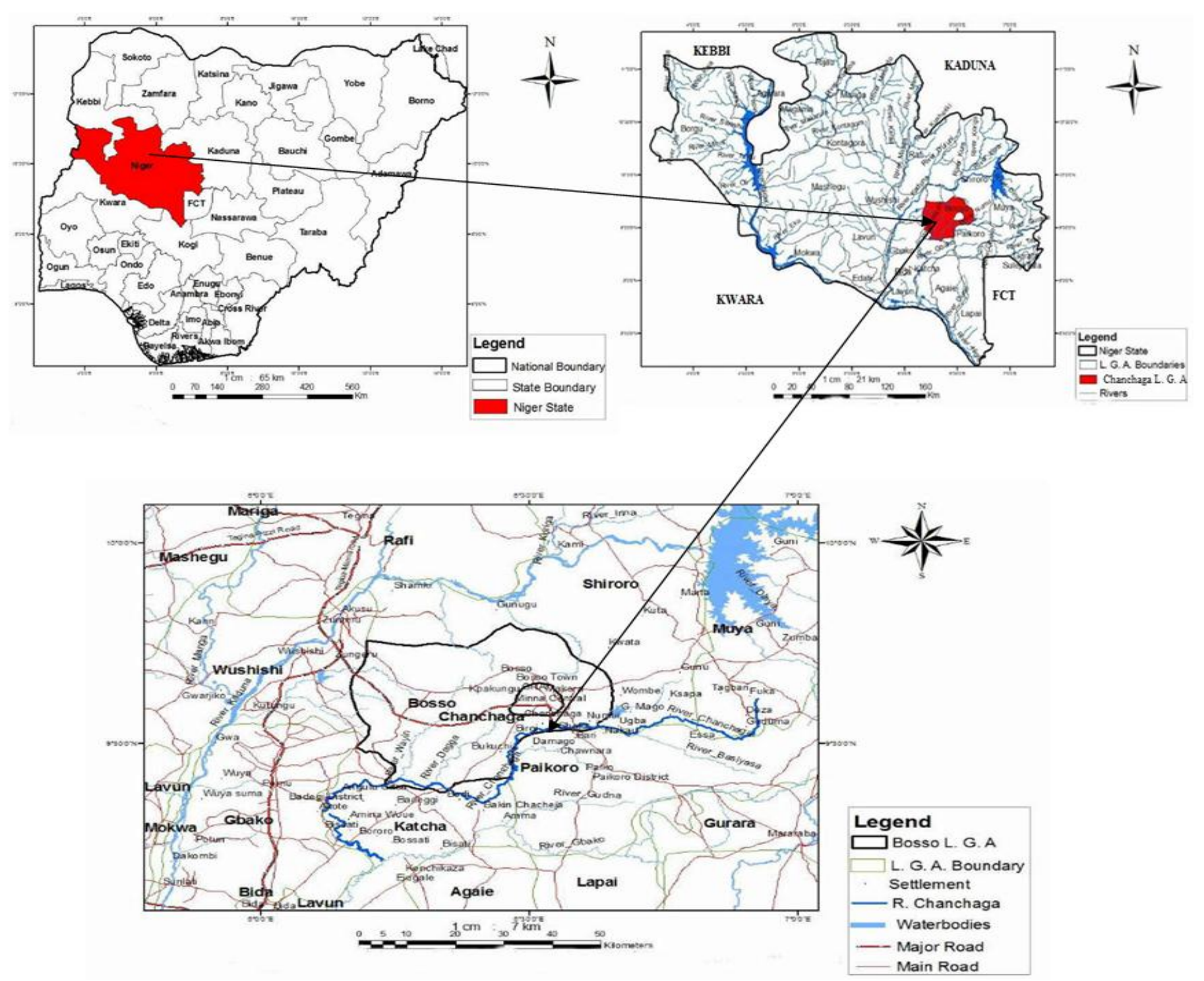

Figure-1. The Study Area (River Chanchaga, Niger State, Nigeria)

Source: Remote Sensing Laboratory, Department of Geography, Federal University of Technology, Minna, Nigeria 


\section{Materials and Method}

The methodology used for this research employed the use of descriptive analysis. It involved the use of tables, charts and simple percentages. Therefore, both quantitative and qualitative measures were used for direct measurement of water channel morphology, river channel characteristics as well as extent of water pollution in the river [8].

Generally, primary data were collected through the field surveys and 250 questionnaires accounting for $0.5 \%$ of the total population of the study area were administered to ascertain salient environmental features along River Chanchaga. Identification of different types of anthropogenic activities using camera, ranging poles and stones were conducted, investigated and analyzed. Secondary data were collected as well through consultation of books of past related subject matter of the study.

\section{Results and Discussions}

The identification is of different anthropogenic activities along River Chanchaga include deforestation, mining, agricultural practices and other activities like industrial activities, oil droplets from mechanic sites and construction activities

\subsection{Deforestation and its Effects in River Chanchaga Basin}

Deforestation is understood to be an indiscriminating felling of trees or exploitation or clearance of the forest at particular geographical locations without any effort at replacing them. The possible consequences of deforestation vary from one point to another. The study reveals in Figure 2 from site A to K, that site D (under Chanchaga Town Bridge) has the highest intensive cutting down of trees and land clearance; this is because the continuous farming practices (irrigation and normal farming activities are taking place) in all seasons of the year with zero fallow duration. Other sample sites that followed site B include sites G, E, F, H, J and I where tuber and cereal crops farming are at alarming rate because of population pressure as indicated in Figure 2. Site $\mathrm{K}$ has lowest rate of deforestation activities. It was found that farming for tuber and cereal crops is less at this area as presented in Table 1. This resulted into the loss of species and biodiversity in aquatic ecosystem of River Chanchaga due to excessive artificial alteration of study area. The affected areas of deforestation are as presented in Plate 1 and 2.

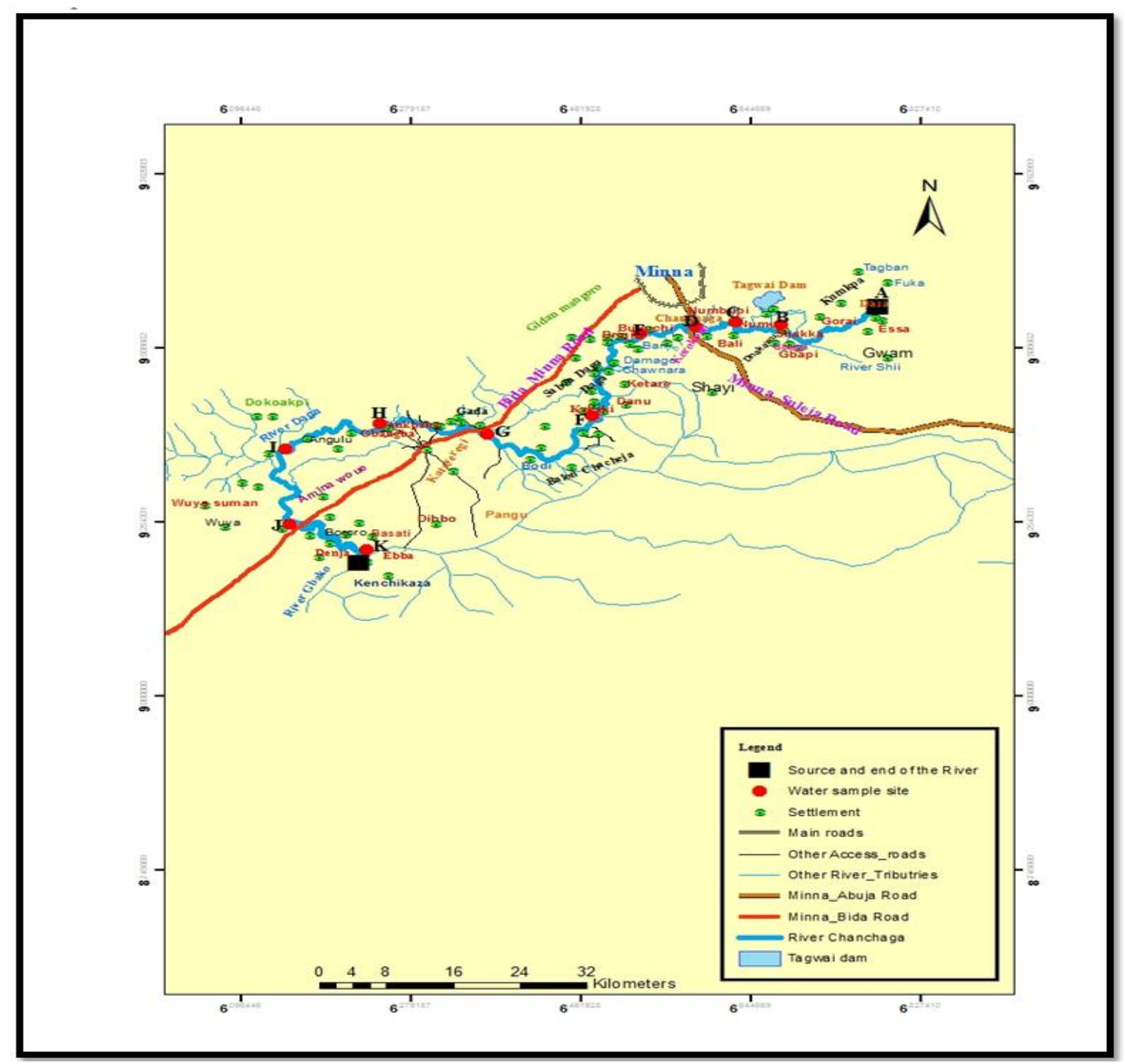

Figure-2. Deforestation around Water Sampling Sites Spatially Distributed along River Chanchaga Source: Department of Geography, Federal University of Technology, Minna

Another source of effect is provision of Fuel Wood and Charcoal: The demand for domestic fuel wood is another factor accelerating deforestation along River Chanchaga. Firewood and charcoal are the main sources of 
energy for domestic purpose as some trees species are particularly important due to the burning efficiency of their wood. The most important are vitexdomianaprosipis Africana, Bonataxcostatum, and Borassusasthiopium. These exploited in large quantities as presented in Plate 1 and 2

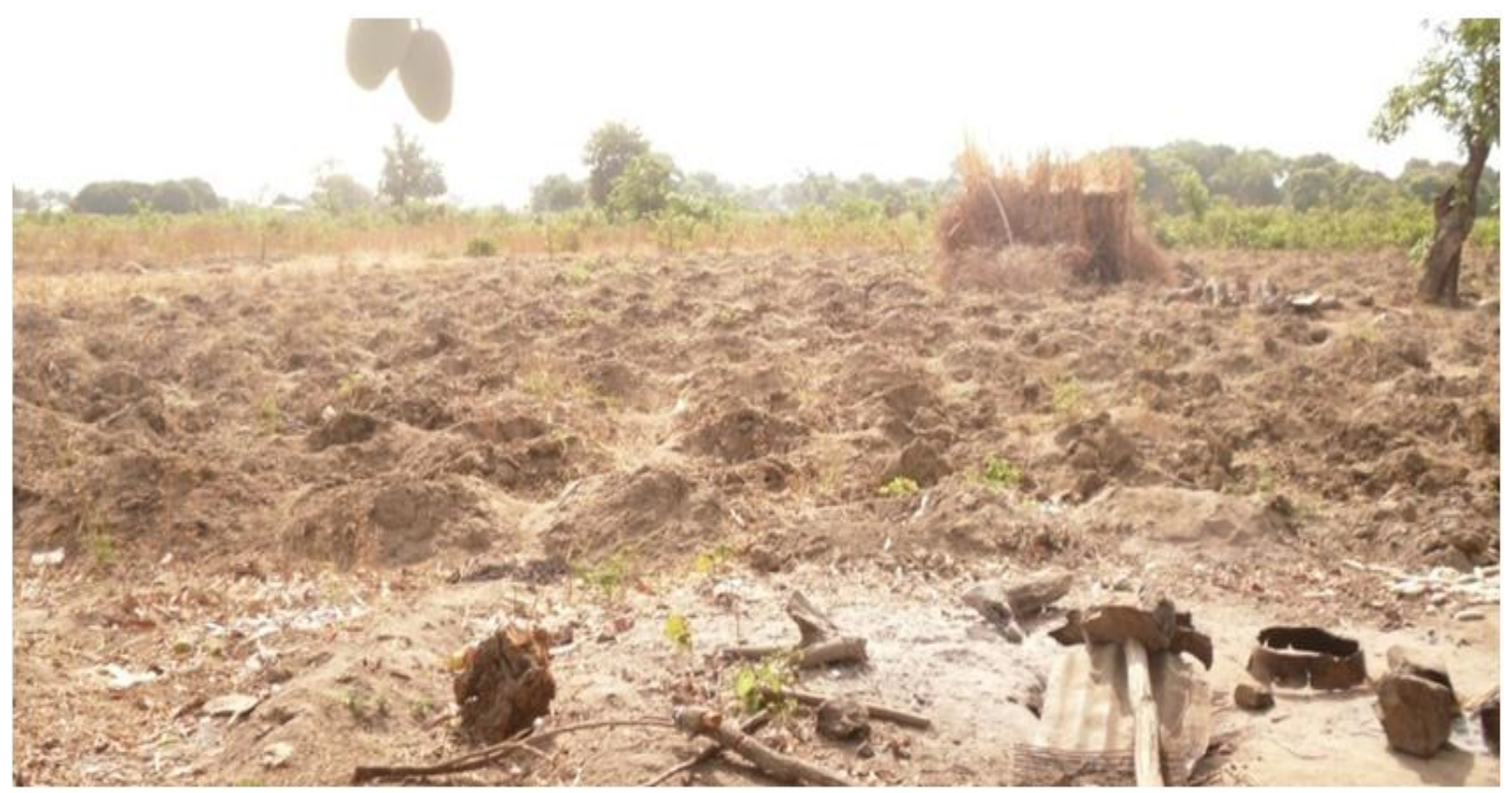

Plate-1. Cutting Down of Trees for Charcoal and Medicinal purposes

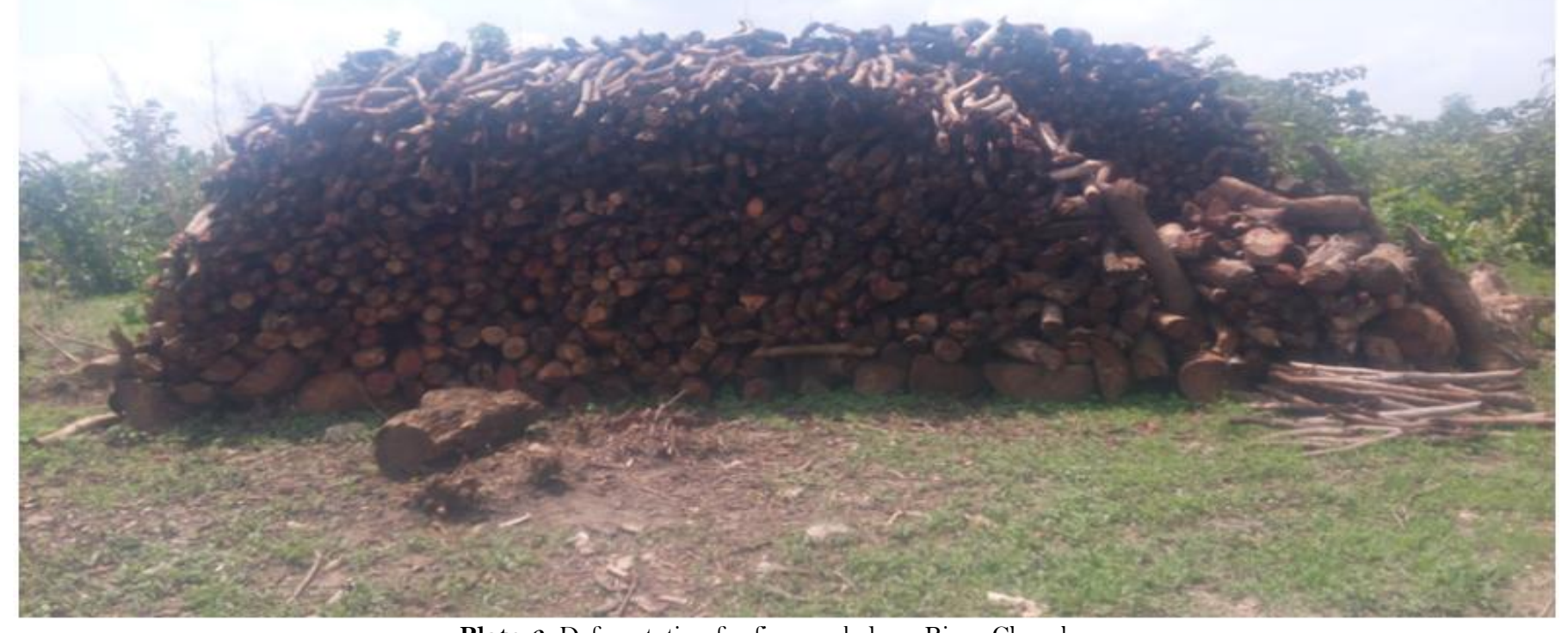

Plate-2. Deforestation for firewood along River Chanchaga

\subsection{Medicinal Properties of the Trees Extraction}

The extractions made from the leaves, branches, barks and roots depend on the type of medicine and intensity of extraction. This may cause tree to die. Other minor causes are settlement and urbanization, farming, construction of roads, building, grazing and mining, which are the major characteristics along the upstream and downstream upland area of River Chanchaga. It was observed that these dead plants wastes get transported by wind and runoff into nearby water source to degrade the water quality in the river as depicted in Plate 1.

\subsection{Farming Activities}

This is deforestation process which involves large scale clearance of vegetation cover for farming due to increasing population at particular geographical areas. The level of disturbance attributed to such land use can either be intermediate or high. The traditional bush fallow cultivation system of River Chanchaga characterized by the annual cycle of forest clearance is no longer tenable. This is cultivation for two to three years and then abandoned for succession to forest. The lengths of the fallow (nowadays) mainly are determined by land availability and population pressure at particular place for specific period. The land clearance for cultivation of food crops and fuel wood is as presented in Plate 3. The farming practices and crops with their subsequence wastes generated that cause's water pollution and eutrophication is presented in Table 1. 
Table-1. Farming Practices, Crop Types and Fallow Duration along River Chanchaga

\begin{tabular}{|c|c|c|c|}
\hline Sample Site Vicinity & Crops Produced & Farming Practices & Duration of Fallow (Years) \\
\hline A & $\begin{array}{l}\text { Maize, guinea corn, } \\
\text { yam, ground nut, millet, } \\
\text { potato }\end{array}$ & $\begin{array}{l}\text { Fertilizer application, mix farming, } \\
\text { bush burning, manure spreading, } \\
\text { grazing of animal, shifting } \\
\text { cultivation }\end{array}$ & 2 \\
\hline B & $\begin{array}{l}\text { Yam, guinea corn, } \\
\text { maize, cassava, fishing, } \\
\text { mango }\end{array}$ & $\begin{array}{l}\text { Fertilizer application, mix farming, } \\
\text { bush burning, manure spreading, } \\
\begin{array}{l}\text { grazing of animal, shifting } \\
\text { cultivation }\end{array}\end{array}$ & 1 \\
\hline $\mathrm{C}$ & $\begin{array}{l}\text { Yam, guinea corn, } \\
\text { maize, millet, cassava, } \\
\text { fishing, mango, guava, } \\
\text { plantain }\end{array}$ & $\begin{array}{l}\text { Fertilizer application, mix farming, } \\
\text { bush burning, manure spreading, } \\
\text { grazing of animal, shifting } \\
\text { cultivation }\end{array}$ & 1 \\
\hline $\mathrm{D}$ & $\begin{array}{l}\text { Rice, yam, guinea corn, } \\
\text { millet, groundnut, } \\
\text { sugarcane, } \quad \text { banana, } \\
\text { potato, mango }\end{array}$ & $\begin{array}{l}\text { Irrigation, } \quad \text { mix } \\
\text { continuous cropping, bush burning, }\end{array}$ & $\mathrm{O}$ \\
\hline $\mathrm{E}$ & $\begin{array}{l}\text { Yam, cassava, millet, } \\
\text { maize, guinea corn, } \\
\text { ground nut }\end{array}$ & $\begin{array}{l}\text { Continuous farming, bush burning, } \\
\text { shifting cultivation }\end{array}$ & 1 \\
\hline $\mathrm{F}$ & $\begin{array}{l}\text { Yam, cassava, millet, } \\
\text { maize, guinea corn, } \\
\text { ground nut }\end{array}$ & Continuous farming, bush burning & 1 \\
\hline G & 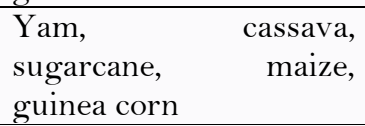 & Continuous farming, bush burning & 2 \\
\hline $\mathrm{H}$ & $\begin{array}{l}\text { Rice, maize, guinea } \\
\text { corn, plantain }\end{array}$ & Fishing, rearing of farm animals & 3 \\
\hline $\mathrm{I}$ & Rice, yam, guinea corn & Shifting cultivation, mix farming & 2 \\
\hline $\mathrm{J}$ & $\begin{array}{l}\text { Rice, yam, maize, } \\
\text { guinea corn }\end{array}$ & Shifting cultivation, mix farming & 2 \\
\hline K & $\begin{array}{l}\text { Rice, yam, guinea corn, } \\
\text { maize }\end{array}$ & $\begin{array}{l}\text { Shifting cultivation, mix farming, } \\
\text { bush fallow }\end{array}$ & 3 \\
\hline
\end{tabular}

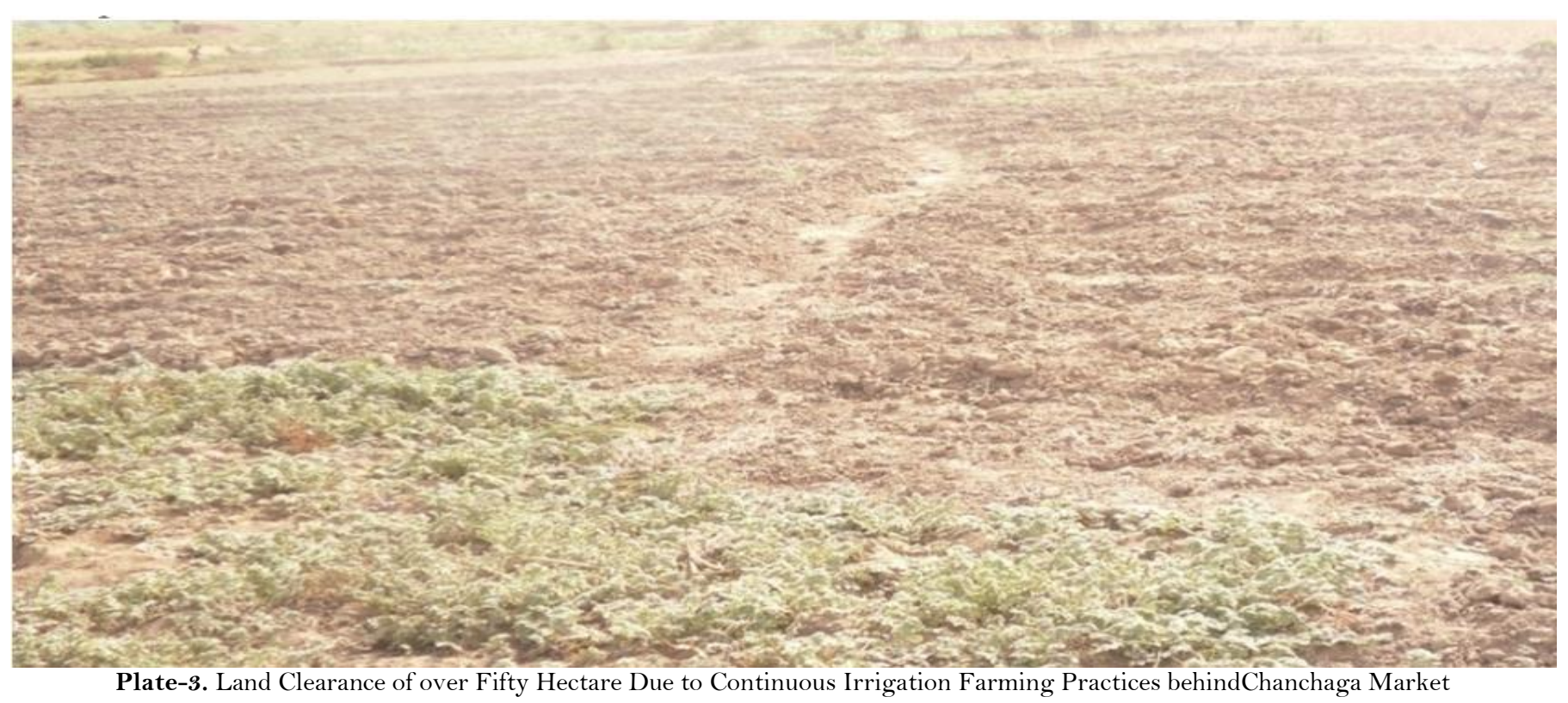

\subsection{Mining Activities}

Mining ranked third with 12 accounting for $4.8 \%$ of the total anthropogenic influences on River Chanchaga water quality as depicted in Table 2.

Table-2. Identified Sites for Mining for Sand and Gold

\begin{tabular}{|c|c|c|}
\hline \multirow[t]{2}{*}{ Course of River Chanchaga } & \multicolumn{2}{|c|}{ Mining Sites } \\
\hline & Sand & Gold \\
\hline Upper & 13 & 12 \\
\hline Middle & 45 & 26 \\
\hline Lower & 7 & 4 \\
\hline Total & 65 & 42 \\
\hline
\end{tabular}

\subsection{Agricultural Practices along the Study Area}

Agricultural practices ranked the highest with 175 accounting for $70 \%$ as indicated in Table 3 and Plate 5. 
Table-3. Anthropogenic Influences on River Chanchaga Water Quality

\begin{tabular}{l|l|l|l}
\hline S/No. & Anthropogenic activities & Frequency (No. of respondents) & Percentage (\%) \\
\hline 1 & Agricultural activities & 175 & 70 \\
\hline 2 & Construction/road \&residential & 38 & 15.2 \\
\hline 3 & Mining activities & 12 & 4.8 \\
\hline 4 & Industrial & 3 & 1.2 \\
\hline 5 & Institutional & 3 & 1.2 \\
\hline 6 & Commercial & 7 & 2.8 \\
\hline 7 & Others & 12 & 4.8 \\
\hline & Total & 250 & 100 \\
\hline
\end{tabular}

Source: Author's Field Work (2016)

\subsection{Irrigation}

Irrigation farming alone with 79 accounting for $31.6 \%$ of the total agricultural activities with other remaining agricultural influence such as animal rearing and upland farming along the river with 96 accounting for $38.4 \%$ making a total of 175 accounting for $70 \%$ of the total agricultural activities shown in Table 3 . Irrigation is the artificial application of water on farm crops in the dry season or during the drought period. It is the major contributor to water pollution especially during dry season period. It was observed that pesticide, fertilizer and other agrochemicals applied on the crops are washed directly into the water body. Chanchaga Town has the highest land area coverage for irrigation farming with about $70 \%$ and the remaining $30 \%$ for other areas along the study area. Irrigation farming practice is as presented in Plate 4.

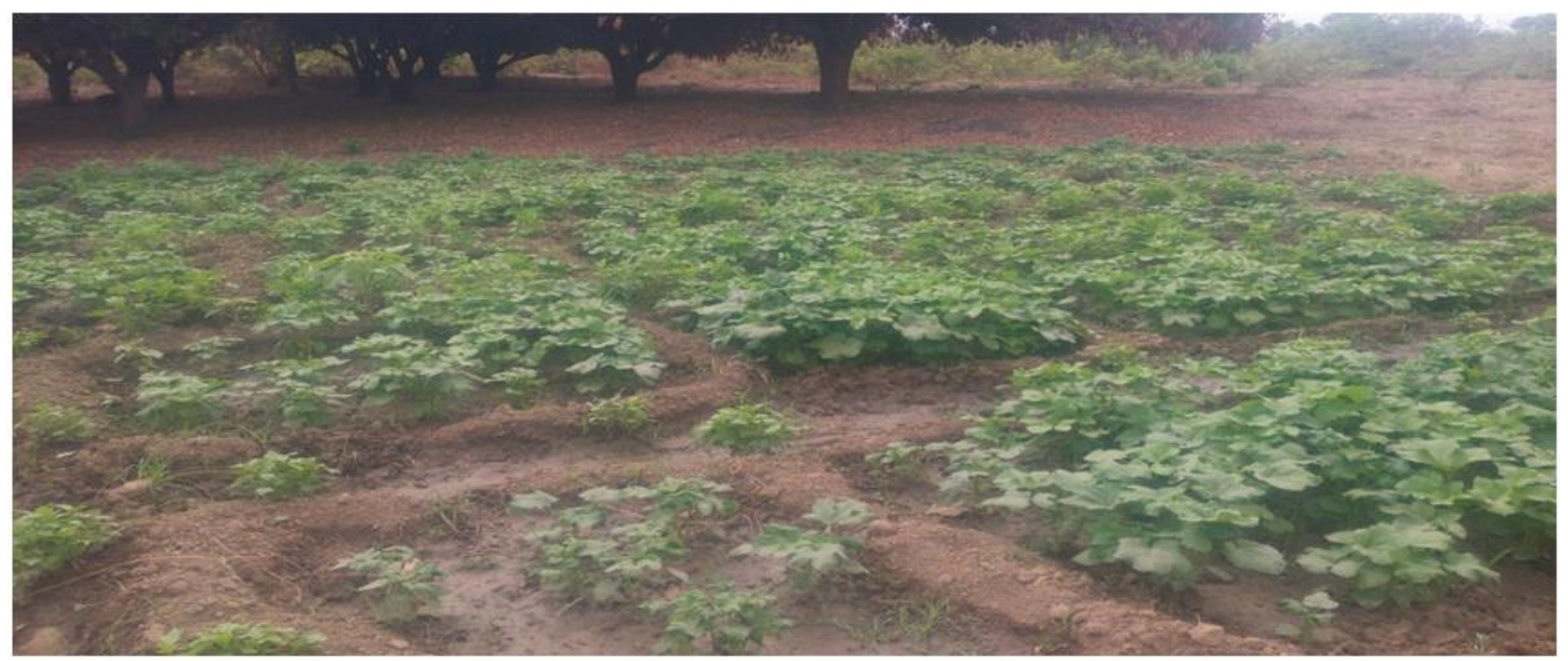

Plate-4. Irrigation Farming Within River Bank.

\subsection{Industrial Activities}

There are five identifiable block industries by Chanchaga Township Bridge, off Minna-Paiko road, three soap factories and one pharmaceutical industry (Danadam Pharmaceutical Industry) that discharge their effluence into River Chanchaga, The effluence and washed detergent discharged degrade water quality in the river, thereby increasing the alkalinity and acidity of this river. Dust from block industries settles immediately after release and increases suspended particles in the water. However, there is less industrial influence on River Chanchaga water quality as they are few light industries along the river. Plate 5 is one of the examples of such anthropogenic activities along the study area.

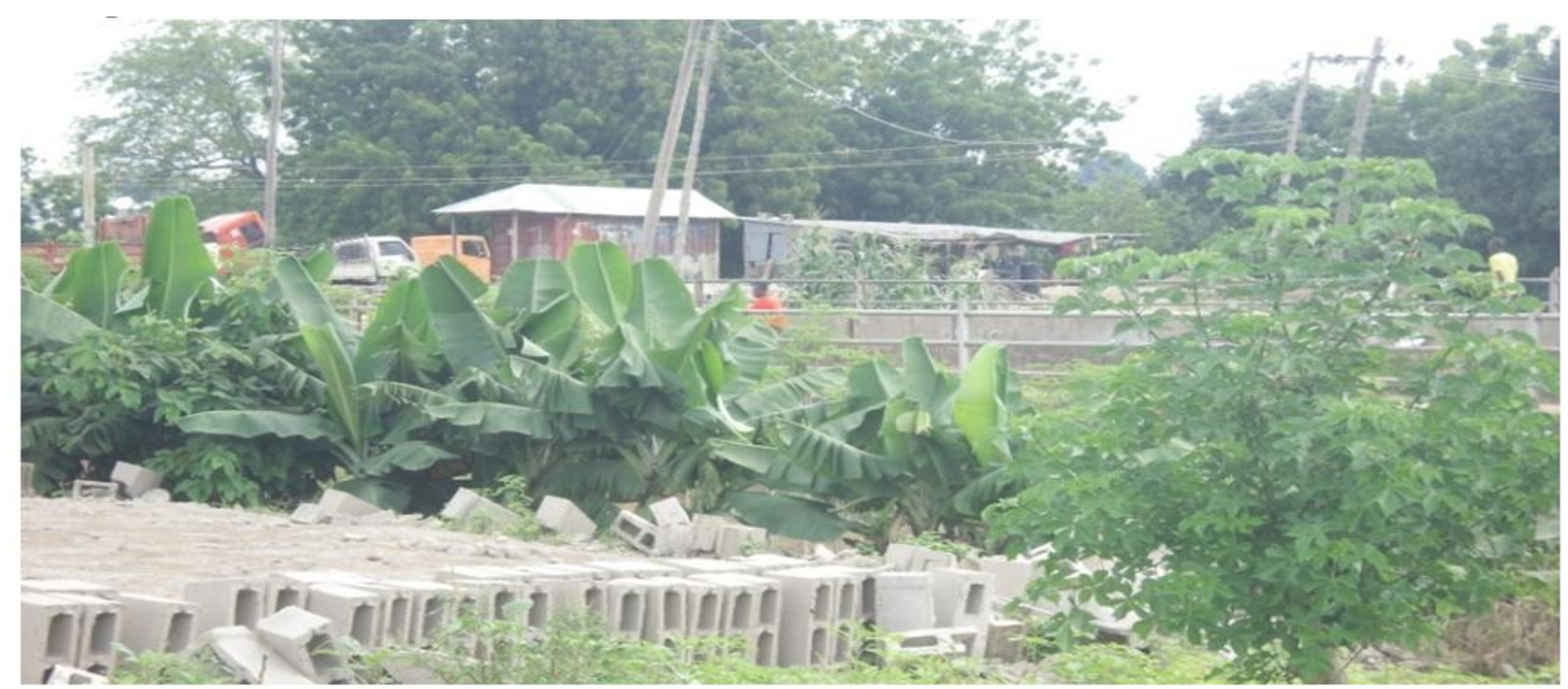

Plate-5. Block Industry with about $8.60 \mathrm{~m}$ Setback to the River Chanchaga 


\subsection{Eutrophication and its Effects on River Chanchaga}

Spatial-temporal eutrophic areas in River Chanchaga are presented in Table 4.

\begin{tabular}{l|l|l|l}
\multicolumn{5}{c}{ Table-4. Spatial-temporal Eutrophic Areas in River Chanchaga } \\
\hline S/N & River course & Frequency & Characteristics \\
\hline 1. & Upper & 5 & Seasonal \\
\hline 2. & Middle & 0 & Not Seasonal \\
\hline 3. & Lower & 0 & Not Seasonal \\
\hline Source: Author's Field Work (2016) & \multicolumn{4}{l}{}
\end{tabular}

The occurrence of eutrophication only at upper course could be as a result of seasonal nature of the river at this part of the study area. This type of degradation products cause knock-on-effect in the form of oxygen deficiency and fish kill.

\section{Conclusion and Recommendations}

Despite the environmental education, it is bound to be complimentary increase of anthropogenic activities in order to satisfy the demand of people residing around the area. Anthropogenic forces are affecting negatively on the natural state of River Chanchaga by reducing the quality and natural beauty of the river surrounding, habitat quality and affect the availability of quality aquatic resources that can served as food and beautifying the riverside environments.

There should be public enlightenment programme so that people will be able to identify the implications of indiscriminate anthropogenic forcing practices along the river. Human activities that may lead to pollution or contamination and eutrophication such as riverside deforestation, irrigation farming and other related environmental issues should be regulated and even discourage. Deforestation should be discouraged to avoid causing ecological imbalance of River Chanchaga aquatic ecosystem.

\section{References}

[1] J. A. Adakole and P. A. Annue, "Benthic macro invertebrates as indicators of environmental quality of an urban Stream Zaria, Northern Nigeria," Journal of Aquatic Science, vol. 18, pp. 85-92, 2003. View at Google Scholar | View at Publisher

[2] S. S. Ogbogu and A. I. Hassan, "Effects of sewage on the physico-chemical variables and ephemeroptera (Mayfly) larvae of a stream-reservoir system," Journal of Aquatic Science, vol. 11, pp. 43-55, 1996. View at Google Scholar

[3] I. Maureen, "Water pollution and its implication for aquatic resources and conservation on River Chanchaga, Minna, Nigeria," Environmental Monitoring and Assessment, vol. 107, pp. 56-64, 2002.

[4] M. Simon, J. Onywere, I. Mironga, and S. Immaculate, "The open environmental engineering," Journal of Environment, vol. 5, pp. 918,2012 .

[5] A. S. Abbakar, Lecture note on environmental management. Minna, Nigeria: Federal University of Technology, 2011.

[6] I. Fahrig, "Relative effect of habitat loss and fragmentation in population existation," Journal of wild Life Management, vol. 61 , pp. 603-610, 1997. View at Google Scholar | View at Publisher

[7] A. S. Halilu, "Water pollution lecture Notes on environmental hazards at federal university of technology, Minna, Niger State, Nigeria," 2001.

[8] B. Y. Muhammad, "An assessment of the effect of channelized River suka drainage project on the physical environment downstream in Minna, Niger State, Nigeria," 2012. 